PART II. PHYSICAL ACTIVITY OF SOCIAL AND PROFESSIONAL GROUPS DZIAŁ II. AKTYWNOŚĆ FIZYCZNA GRUP SPOŁECZNYCH I ZAWODOWYCH

\title{
FUNCTIONAL STATUS OF THE CENTRAL NERVOUS SYSTEM IN GIRLS AGED 16-18 YEARS OLD
}

\section{STAN FUNKCJONOWANIA OŚRODKOWEGO UKŁADU NERWOWEGO DZIEWCZĄT W WIEKU 16-18 LAT}

\author{
Anatolii Bosenko ${ }^{1(A, B, C, D, E, F, G)}$, Olena Bobro ${ }^{1(A, B, C, D, E, F, G)}$, \\ Mariia Topchii ${ }^{1(A, B, C, D, E, F, G)}$, Serhii Kholodov ${ }^{1(A, B, C, D, E, F, G)}$
}

\begin{abstract}
${ }^{1}$ Department of Biology and Health, South Ukrainian National Pedagogical University named after K. D. Ushynsky, Odessa, Ukraine
\end{abstract}

Authors' contribution Wkład autorów: A. Study design/planning zaplanowanie badań B. Data collection/entry zebranie danych C. Data analysis/statistics dane - analiza i statystyki D. Data interpretation interpretacja danych E. Preparation of manuscript przygotowanie artykułu F. Literature analysis/search wyszukiwanie i analiza literatury G. Funds collection zebranie funduszy
Tables: 2

Figures: 2

References: 41

Submitted: 2019 Jul 17

Accepted: 2019 Sep 23

\section{Summary}

Background. The objective of the study was to explore the dynamics of the functional state of the central nervous system (CNS) and neurophysiological processes of girls 16-18 years old in the context of their transition to a new level of social organization.

Material and methods. The functional state of the CNS was studied in girls 16-18 years old in a state of relative muscular rest through observation of visible motive reactions, Loskutova's method, and in the fifth minute of renewal after the physical loading with variable power.

Results. We found that 17 year-old girls had the best functional CNS capabilities. The reduced adaptive capacity of the CNS in 16 year-old girls is due to their necessity for adaptive reorganization of regulatory mechanisms to new social conditions: examinations and university entry. After physical activity, 16 and 18 year-old girls registered stress reactions, indicating decreased CNS adaptation.

Conclusions. 17 year-old girls were observed at rest to have better CNS functionality compared to the other age groups. Analysis of the dynamics of the functional CNS states of 16-18 year-old girls after exercise resulted in the identification of two main reaction types: 1) reduction of the basic criteria at high initial values; 2) increase of criteria of a general functional state of a brain at low raw data.

Keywords: central nervous system, general functional state, load, youth period, simple visualmotor reaction

\section{Streszczenie}

Wprowadzenie. Celem pracy było zbadanie zmian funkcjonowania ośrodkowego układu nerwowego oraz specyfiki procesów neurofizjologicznych u dziewcząt w wieku 16-18 lat w wyniku przejścia na nowy poziom organizacji społecznej.

Materiał i metody. Stan funkcjonowania ośrodkowego układu nerwowego był badany u dziewcząt w wieku 16-18 lat na podstawie przestojów widocznych reakcji motywacyjnych metodą T. Loskutova w stanie relatywnego odpoczynku mięśniowego i w piątej minucie odnowy po obciążeniu fizycznym o zmiennej mocy.

Wyniki. Wyniki badań wykazały, że dziewczęta w wieku 17 lat miały najlepsze możliwości funkcjonalne ośrodkowego układu nerwowego. Zmniejszenie zdolności adaptacyjnych ośrodkowego układu nerwowego u dziewczątw wieku 16latwynika z koniecznościreorganizacji i przystosowania mechanizmów regulacyjnych do nowych warunków społecznych: egzaminów i przyjęcia na uniwersytet. Po aktywności fizycznej u dziewcząt w wieku 16 i 18 lat zaobserwowano reakcję stresową, która wskazuje na obniżenie mechanizmów adaptacyjnych ośrodkowego układu nerwowego.

Wnioski. U dziewcząt w wieku 17 lat w stanie odpoczynku zaobserwowano lepsze funkcjonowanie ośrodkowego układu nerwowego $\mathrm{w}$ porównaniu $\mathrm{z}$ innymi grupami wiekowymi. Analiza zmian w stanie funkcjonowania ośrodkowego układu nerwowego u dziewcząt w wieku 16-18 lat po wysiłku pozwoliła zidentyfikować dwa główne typy reakcji: 1) obniżenie podstawowych kryteriów przy wysokich wartościach początkowych; 2) wzrost kryteriów ogólnego stanu funkcjonowania mózgu przy niskich danych surowych.

Słowa kluczowe: ośrodkowy układ nerwowy, ogólny stan funkcjonowania, obciążenie, okres młodzieńczy, prosta reakcja wzrokowo-ruchowa 


\section{Introduction}

The period of youth is characterized by a variety of changes in all functional systems of the body: the end of growth, development and transition to an adult level. At this time, all systems establish cooperation. Girls synchronize their reproductive system by strengthening neurohormonal connections between the central nervous system (CNS) and hypophysis and peripheral links with the ovaries. The role of the cerebral cortex in adjusting the body's functions increases, the strength of nervous system processes changes, the ratio of excitation to inhibition in the CNS aligns and autonomic nervous system ripening completes [1, 2]. All transformations are closely related to the changes in the relationship between the endocrine and nervous systems. So if in adolescence the influence of hormonal mechanisms of regulation over the nervous system prevails, as a result of ontogenetic alterations, new relationships with a prevalence of influence of the nervous mechanisms of regulation of all systems are established $[3,4,5,6]$. Knowledge of these phenomena becomes more relevant in the context of studying the transition processes from one educational system, high school, to another, that of higher education institutions. Consequently, the mechanisms of central and humoral control over human abilities during this period come to the fore $[7,8,9,10]$.

The main activity in adolescence is education, and ultimately appropriate and successful professional orientation towards a future specialty [11]. The manifestation of activity in the social sphere results in nervous system activation, which is the basis for the implementation of intellectually mnestic activities. The CNS provides information transformation, carries out its processing and produces target answers, i.e., commands for sustained actions aimed at the achievement of positive results for the organism $[12,13,14,15,16,17]$. Therefore, an important role is played by the evaluation of various characteristics of the adaptive and compensatory mechanisms of the youthful organism while changing school systems. This alteration in the main nervous processes can be detected by diagnosing sensorimotor reactions illustrating the interaction between mental and neurophysiological mechanisms and are the basis of successful intellectual activity [18, 19]. The study of indicators of sensorimotor reactions is used in neurophysiological studies of different population segments [20, $21,22,23,24,25,26]$.

In a field this diverse, we study the dynamics of basic criteria characterizing the CNS functions of girls of different ages. The importance and necessity of this kind of research is well recognized [24, 27, 28, 29, 30, 31]. Our work is devoted to the study of the problem of the general functional state (GFS) of the CNS and peculiarities in the neurophysiological processes taking place in 16-18 year-old girls in the context of their transition to a new level of social organization.

To achieve the main goal, we have identified the following tasks:

1. to study the main criteria for estimation of the general functional state of the CNS of girls 16-18 years old in a state of relative muscle rest;

2. to investigate the dynamics of the general functional state of the brain of girls 16-18 years old in the implementation of burden with variable power;

3. to conduct comparative analysis between the studied criteria of girls 16-18 years old.

\section{Material and methods}

The research was carried out in the Tsoneva Laboratory of Age Physiology of Sports, Department of Biology and Health of the State Institution "Ushynsky South Ukrainian National Pedagogical University". 51 16-18 yearold girls were examined, and divided into three groups: group I - 16 year-olds (n=23); group II - 17 year-olds $(n=12)$; and group III - 18 year-olds $(n=16)$.

The study was conducted in accordance with the basic provisions of the Council of Europe Convention on Human Rights and Biomedicine (dated $4^{\text {th }}$ April 1997), and Helsinki Declaration of the World Medical Association on ethical principles of conducting scientific medical research with the participation of a person (1994-2008).

The dynamics of the functional state of CNS was studied by means of Reflexometry by the method of T. Loskutova [9, 32, 33]. To measure the time of a simple visual-motor reaction, the Lightning device developed and patented by Bosenko was used [34].

Research was conducted as follows: the surveyed, in response to light stimuli, have to quickly press a button with the thumb of their "working" hand. The reaction time is displayed on the experimenter's indicator, recorded and memorized. In total, there are 60 signals in the series, an interval between each varies between 3 and 6 seconds, in order to avoid reflex actions based on set times. The test duration is up to 6 minutes. Research terms are limited by afferent effects, that is instrumental in the decline of tone of CNS. Thus, instruction requires pressing the button as quick as possible, so that motivation is utilized to promote tone of the nervous system. In this way, conditions were created to identify the abilities to formulate and appropriately maintain a functional brain state [7,9]. 
According to the time of the latent period of the visual-motor reactions, a graph of the distribution of values is constructed, characterizing the individual level of the general functional brain state and also the protocol of inspection with the sizes of three indexes unsealed - functional level of the system (FLS), reaction stability (RS) and level of functionality (LF) and significance of 60 latent periods.

Upon receiving instruction in the moment of organization of ready condition, the functional system forms to realize a simple motive reaction. Its formation is related to the necessity of association of the different functional specialized nerve centers for the unique system which, in turn causes coherence of time parameters for these centers in synchronizing their activities [32, 33, 35]. It is necessary to note that based on the influence by modality and intensity of the irritant and the level of complexity and automation of the irritant and the functional readiness of the nervous system, the latent period can vary considerably. However, the time of the reaction-answer for a stimulus cannot be below a certain physical limit or "uncontinuous minimum" of about 100 milliseconds [36].

Reflexometry was carried out in a state of relative muscle relaxation and at the fifth minute of recovery after physical bicycle ergometric load, as carried out according to the methodology of D. Davydenko and coauthors [37]. According to this method, the load power increased continuously at constant speed (33 W per minute) from zero to a certain level determined by the heart rate of 150 beats per minute, whereupon it dropped to zero with the same speed. The frequency of pedaling for all surveyed was identical at 60 revolutions per minute. The rotation (reverse) of load was performed at the same time for all tested heart rates (150 to 155 beats/min) that is, at the same physiological price, the surveyed reached a different load capacity.

Statistical analysis of data was performed using the statistical package SPSS 16. The critical level of significance in checking statistical hypotheses was assumed to be $\mathrm{p} \leq 0.05$. To describe selective distribution, $\mathrm{M}$ indicated the arithmetic mean and $\mathrm{m}$ indicated the error of the arithmetic mean. In order to study the effect of loads on the functional state of the studied system for comparison of two dependent selections, the Wilcoxon criterion was applied [38].

\section{Results}

The comparative characteristics of the studied parameters of the general functional state (GFS) of brain in norm for girls (youth period of ontogenesis) and in adults are presented in Table 1.

Table 1. Indices of the general functional state of the CNS in the state of relative muscular rest of girls of youth age and adults

\begin{tabular}{|c|c|c|c|c|}
\hline \multirow{2}{*}{$\begin{array}{c}\text { Criteria of functional state } \\
\text { CNS, c. } \mathbf{u} .\end{array}$} & \multicolumn{4}{|c|}{ Contingent } \\
\cline { 2 - 5 } & $\begin{array}{c}\mathbf{1 6} \text { years old } \\
(\mathbf{n = 2 3 )}\end{array}$ & $\begin{array}{c}\mathbf{1 7} \text { years old } \\
\mathbf{( n = 1 2 )}\end{array}$ & $\begin{array}{c}\text { 18 years old } \\
\text { (n=16) }\end{array}$ & $\begin{array}{c}\text { Adults } \\
\text { (Loskutova's } \\
\text { method) }\end{array}$ \\
\hline $\begin{array}{c}\text { Functional level of the } \\
\text { system (FLS) }\end{array}$ & $4.75 \pm 0.07$ & $4.61 \pm 0.09$ & $4.74 \pm 0.06$ & $4.2-5.5$ \\
\hline Reaction stability (RS) & $1.93 \pm 0.10$ & $1.67 \pm 0.12$ & $2.03 \pm 0.12^{*}$ & $1.0-2.8$ \\
\hline Level of functionality (Lf) & $3.61 \pm 0.11$ & $3.23 \pm 0.10$ & $3.66 \pm 0.12^{*}$ & $2.7-4.0$ \\
\hline
\end{tabular}

Note: ${ }^{*} \mathrm{p}<0.05$ in relation to 17 year-old girls; c. u. - conventional units

According to the reference values, the magnitude of the functional level of the system, reaction stability and level of functionality using Loskutova's method, all surveyed can be divided into three main groups: the lowest, highest and middle functional center of the CNS. The optimum, according to many scientists, is the average level of activation (tone) of the brain [9, 30].

According to the indicators of stability of the reaction (Figure 1), the average level of the general functional state of the brain was observed in $34.78 \%$ of 16 year-old girls, $58.33 \%$ of 17 year old girls and $31.25 \%$ of 18 yearold girls. A higher percent with a high functional CNS level is registered in 18 year-old girls (62.5\%), with the lowest in 16 year-old girls (26.09\%).

Based on the values of the functional level of the system, which is characterized by mechanisms representing tension of tonic non-specific influences, the middle level of GFS in the brain was determined in $43.48-58.33 \%$ of girls aged 16-18 years old. Moreover, a higher percent fell on the first course of studies, and the lower percent in the 16 year-old girls.

Only by the integrative index of the functional state of the CNS - a level of functional capabilities allowing us to judge the ability of the nervous system to formulate and maintain a functional system for a long time - there was an increase in the average level of the surveyed 17 and 18 year-old girls compared to 16 year-old girls: $43.48 \%$ - girls of I group; $66.67 \%$ - girls of group II and $62.5 \%$ - girls of group III. 


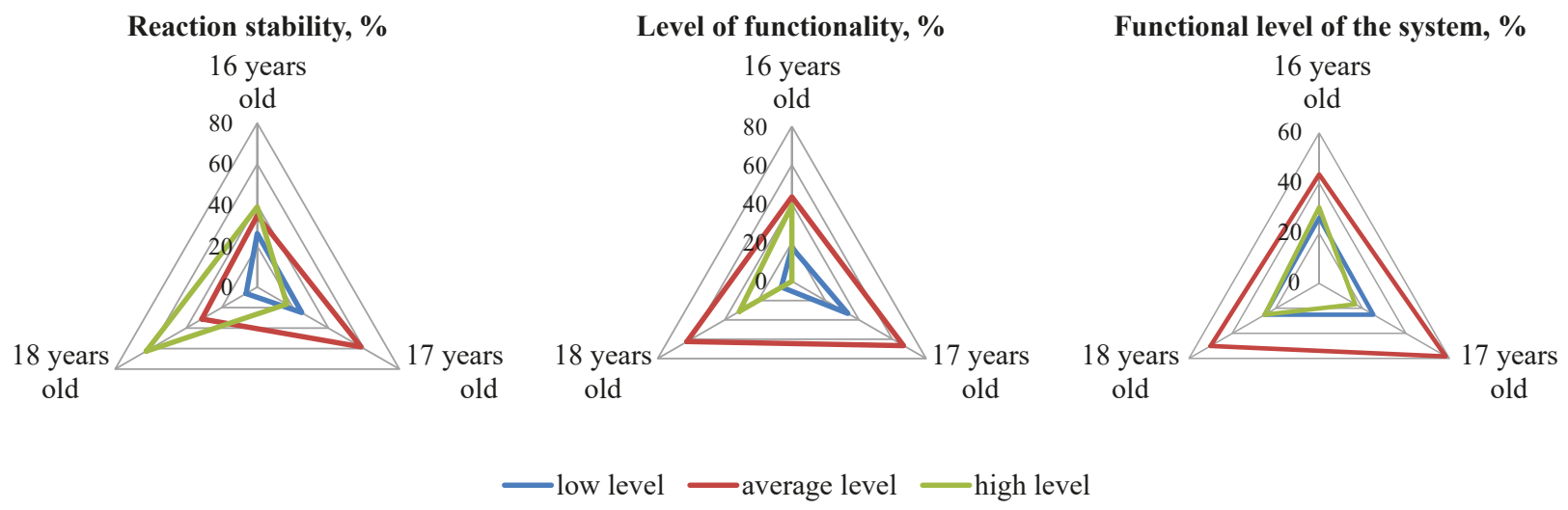

Figure 1. Levels of the general functional state of the brain of girls aged 16-18 in a state of rest (based on Loskutova)

Under the effect of dosed physical activity in a closed cycle, the probed indices of surveyed girls changed differently: there was an increase and decrease of indicators in different age groups. For the type of pattern established, we identified two main types of dynamics of the GFS parameters of the surveyed brain at metered load with reverse. They differ in orientation, depth of developments and quantitative ratio: with a high level of brain functional state, as a rule, decreasing in indicators, and at low output values, an increase in criteria (Figure 2).
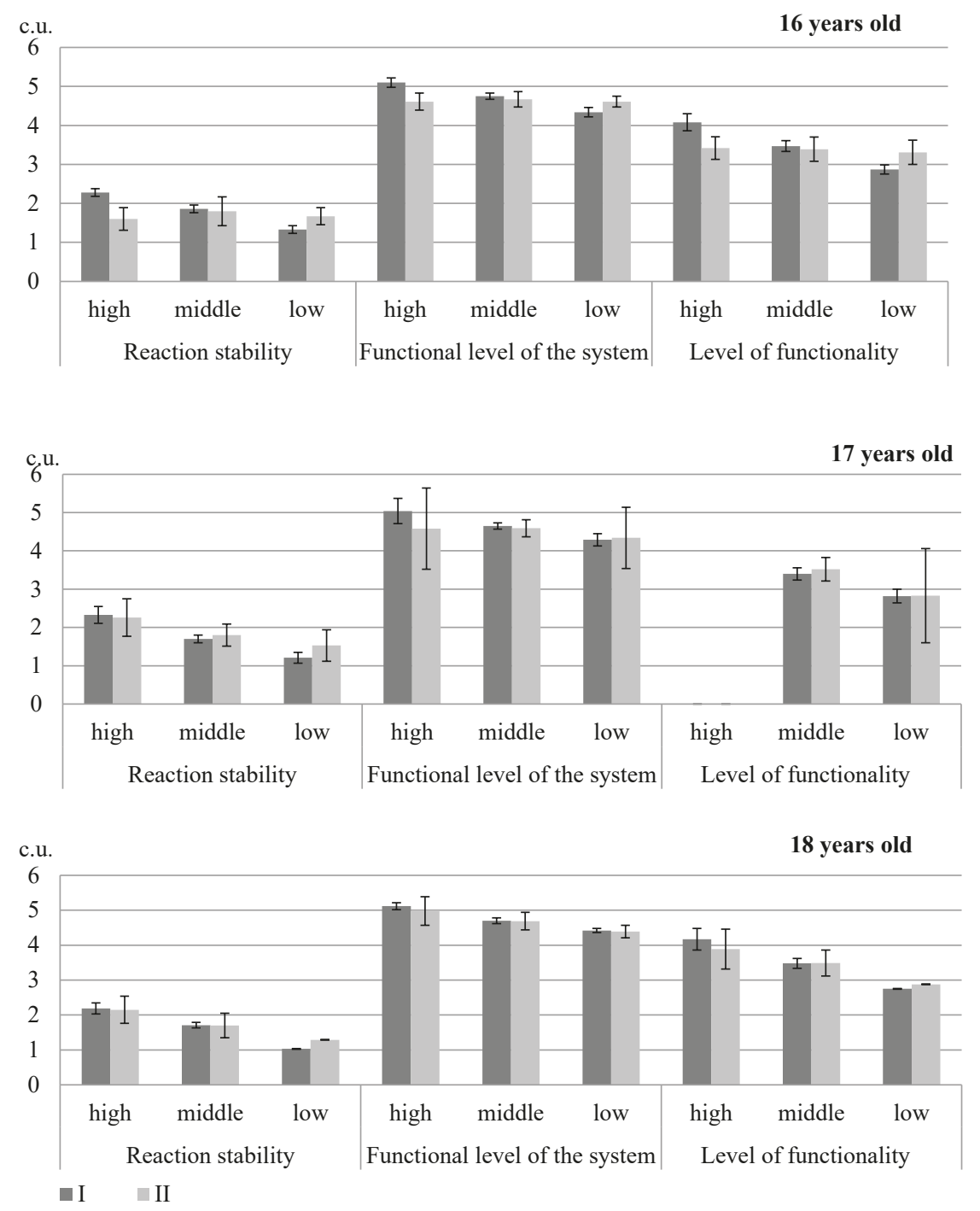

I - state of the relative muscular rest, II - fifth minute of restoration after a physical load

Figure 2. Changes in indicators of general functional state of the brain in girls aged 16-18 years old after physical activity 
The identified features are consistent and confirm previously noted regularities in the reaction of the functional CNS state to a wide range of surveyed both on mental, and on metered-dose and maximum muscular load $[3,9,32]$. There is also a third type of reaction to the GFS of the brain - an absence of similar or multidirectional changes of the studied parameters. This type is considered rigidity in the system and response inadequacy.

\section{Discussion}

In this study of a comparative analysis of reflexometry in the relative rest state of the three age groups, we found that 17 year-old girls had the best CNS functionality. Leaving school is the beginning of a new social phase in the lives of adolescents. So a slight percent reduction in CNS criteria in girls of group I, in our opinion, due to the need for adaptive restructuring of regulatory mechanisms to the new social conditions of man: examinations and university entry. A similar distribution can also be explained by the fact that girls at this age have not yet fully and functionally formed brain structures, and the maturation and development processes of the body as a whole are not complete. It is also possible to relate the results to the features of the adjustment and compensation processes occurring in the youth's body and endocrine remodeling accompanying this age period of ontogeny $[12,39,40]$.

Reduction of regulatory mechanisms of the CNS in the surveyed 18 year-olds is confirmed by longitudinal studies of youth functionality carried out in the Tsoneva Laboratory of Age Physiology of Sports from 20142018. Studies have established the strain of adaptive capacity regulatory systems of the youth body at age 18 [33]. To assess the dynamics of the functional state of the CNS on the load of different orientation, the use of the methodical proposals of Baevskiy and Berseneva has been suggested previously [41]: shift in the $\pm 25 \%$ range is considered an activation reaction, $\pm 50 \%$ - stress response of regulatory mechanisms, and changes within $\pm 50 \%$ - overexertion response with possible failure of adaptive mechanisms. In our view, this approach gives a more objective individual description of the adaptive reactions of the CNS to physical and mental load and possibly other factors. Consequently, our research into simple visual motor reactions after physical activity have established that the stability of the reaction of tension of the regulatory systems of the CNS was observed in almost half the 16 year-old girls (43.47\% of cases) and less in the 17 and 18 year-olds (33.33\% and 31.25\%, respectively) (Table 2). The resilience of response reflects the stability of the functional CNS state. Therefore, the less dispersion of response time, the tighter its distribution.

Table 2. The range of deviations of the reference level of indicators of the functional state of the CNS of girls aged 16-18 years old after physical activity in a closed cycle (\%)

\begin{tabular}{|c|c|c|c|c|}
\hline Improvement, \% & Groups of girls & FLS & SR & LF \\
\hline \multirow{3}{*}{ $\pm 25 \%$} & 16 years old & 100 & 47.83 & 82.61 \\
\hline & 17 years old & 100 & 66.67 & 100 \\
\hline & 18 years old & 100 & 68.75 & 87.50 \\
\hline \multirow{3}{*}{$\pm \mathbf{5 0} \%$} & 16 years old & 0 & 43.47 & 17.39 \\
\hline & 17 years old & 0 & 33.33 & 0 \\
\hline & 18 years old & 0 & 31.25 & 12.50 \\
\hline \multirow{3}{*}{$\begin{array}{c}\text { More } \\
\pm 50 \%\end{array}$} & 16 years old & 0 & 8.70 & 0 \\
\hline & 17 years old & 0 & 0 & 0 \\
\hline & 18 years old & 0 & 0 & 0 \\
\hline
\end{tabular}

Note: FLS - functional level of the system, RS - reaction stability, LF - level of functionality

By the functional level of the system, girls of all age groups showed reaction activation. However, by level of functionality, as an integral criterion for the CNS, some differences were also recorded. Indeed, all surveyed 17 year-old girls, who studied at the first year at the university, the positive dynamics of this criterion is revealed. However, girls of other age groups were registered with the reaction of tension of the regulatory systems of the CNS: $17.39 \%$ in 16 year-olds and $12.50 \%$ in 18 year olds, indicating CNS fatigue after physical activity and a need to increase the recovery period after completing physical activity. Voltage response that registered on the physical activity of surveyed 16 and 18 year-old girls also testifies to declining CNS adaptation in the surveyed girls of these age groups. It can be concluded that these age periods are transitional in the youth period.

In summary, we found that identifying the functional CNS status using the time of a simple visual motor reaction represents physiological processes, occurring in the brain at rest and with certain load types. With a great deal of reliability, this method measures the adaptive and compensatory reserves during ontogenesis. 
The method expands and complements knowledge about the adaptation of adolescents as measured using other methods.

\section{Conclusions}

17 year-old girls in a state of rest had the best functional possibilities of the CNS compared to other age groups.

Analysis of the dynamics of the functional CNS state in 16-18 year-old girls after implementation of physical load allowed the identification of two main types of reaction: 1) a decline in basic criteria at high initial values; 2) an increase of GFS values of the brain at low initial data.

The physical load with the change of power revealed 16 and 18 year-old girls have tension response of regulatory mechanisms that illustrates decreased adaptation mechanisms of the CNSs of these girls.

The reflexometry method adequately reflects the physiological processes of the brain and can be used to get additional information in the application areas of physiology, sports medicine, and psychology.

\section{Disclosures and acknowledgements}

We thank all members of the research team. The authors declare no conflict of interest regarding this article. The authors declare that all the procedures and experiments of this study respect the ethical standards in the Helsinki Declaration of 1975, as revised in 2008(5), as well as national laws. The study was approved by the ethics committee. Informed consent was obtained from all the subjects included in the study. There was no funding for this study.

\section{References:}

1. Blakemore S, Choudhury S. Development of the adolescent brain: implications for executive function and social cognition. Journal of Child Psychology and Psychiatry. 2006; 47(3-4): 296-312. https://doi.org/10.1111/j.1469-7610.2006.01611.x

2. Telzer EH, Fuligni AJ, Lieberman MD, Miernicki ME, Galván A. The quality of adolescents' peer relationships modulates neural sensitivity to risk taking. Social Cognitive and Affective Neuroscience. 2015; 10(3): 389-398. https://doi.org/10.1093/scan/nsu064

3. Bosenco AI, Topchii MS. General functional state of the central nervous system of the first and second year students of the physical education faculty. Science Rise: Biological Science. 2017; 4(7): 31-36. https://doi.org/10.15587/2519-8025.2017.109302

4. Dehtiarenko TV. [Psychophysiology of early ontogenesis. Textbook]. Kyiv: UAIP “Rada”; 2011 (in Ukrainian).

5. Ivanov VD, Kokareva EG. [Psychophysiological qualities of individual and first year students' motion activity]. Bulletin of Chelyabinsk State University. 2014; 13(342): 60-67 (in Russian).

6. Steiner H, Ryst E, Berkowitz J, Gschwendt MA, Koopman C. Boys' and girls' responses to stress: affect and heart rate during a speech task. Journal of Adolescent Health. 2002; 30(4 Suppl. 1): 14-21. https://doi.org/10.1016/S1054-139X(01)00387-1

7. Antropova MV, Kuznecova LM, Paranecheva TM. [Mental performance and its features in the holy with puberty in schoolchildren aged 11-13 years]. Human physiology. 2006; 32: 124-131 (in Russian).

8. Arutjunjan AA. [The weakening of competitive tension in sportsmen after verbal psychoregulation]. Human physiology. 2004; 30: 135-137 (in Russian).

9. Bosenko AI. [Methodological bases of adaptive capacities basic school pupils in physical education (extended abstract of candidate's thesis)]. Chernihiv: Chernihiv National Pedagogical University named after Taras Shevchenko; 2017 (in Ukrainian).

10. Raphael L, Burke M. Academic, social, and emotional needs in a middle grades reform initiative. Research in Middle Level Education Online. 2012; 35(6): 1-13. https://doi.org/10.1080/19404476.2012.11462089

11. Van Leijenhorst L, Moor BG, de Macks ZAO, Rombouts SA, Westenberg PM, Crone EA. Adolescent risky decisionmaking: neurocognitive development of reward and control regions. NeuroImage. 2010; 51(1): $345-355$. https://doi.org/10.1016/j.neuroimage.2010.02.038

12. Bezrukih MM, Loginova ES. [Age dynamics and features of the formation of psycho-physiological structures of intellect in primary school students with different learning successes]. Human physiology. 2006; 32: 1525 (in Russian).

13. Makarenko MV, Lizogub VS. [Ontogenesis of psychophysiological functions of a person]. Cherkasy: Vertical; 2011 (in Ukrainian). 
14. Makarchuk MY, Kutsenko TV, Kravchenko VI, Danilov SA. [Psychophysiology: a textbook]. Kyiv: LLC «Interservice»; 2011 (in Ukrainian).

15. Rechkalov AV, Shubin MV, Kargapolec AG, Shimchenko MV, Medvedeva SV, Tjukalova MA. [Influence of mascular and food loading on gastrin concentration in blood serum of persons with different levels and specific characters of everyday motor activity]. Bulletin of KSU. 2013; 9: 16-20 (in Russian).

16. Wolf S, Brölz E, Keune PM, Wesa B, Hautzinger M, Birbaumer N, et al. Motor skill failure or flow-experience? Functional brain asymmetry and brain connectivity in elite and amateur table tennis players. Biological Psychology. 2015; 105: 95-105. https://doi.org/10.1016/j.biopsycho.2015.01.007

17. Buchanan CM, Eccles JS, Becker JB. Are adolescents the victims of raging hormones? Evidence for activational effects of hormones on moods and behaviors at adolescence. Psychological Bulletin. 1992; 111(1): 62-107. https://doi.org/10.1037/0033-2909.111.1.62

18. Casey BJ, Giedd JN, Thomas KM. Structural and functional brain development and its relation to cognitive development. Biological Psychology. 2000; 54(1-3): 241-257. https://doi.org/10.1016/S0301-0511(00)00058-2

19. Spear LP. The adolescent brain and age-related behavioral manifestations. Neurosci Biobehav Rev. 2000; 24(4): 417-63. https://doi.org/10.1016/S0149-7634(00)00014-2

20. Bodnar I, Dukh T, Vovkanych L, Kindzer B. [The speed of sensorimotor reactions and cognitive processes in students of higher educational institutions of the humanities]. Physical activity, health and sport. 2012; 4(10): 3-9 (in Ukrainian).

21. Korobeinikova LH. [Determinant of psychophysiological state of athletes of high qualification with different emotional characteristics]. Pedagogy, psychology, medical-biological problems of physical education and sport. 2011; 4: 94-97 (in Ukrainian).

22. Korobeynikov G, Korobeinikova L, Mytskan B, Cynarsk W. Information processing and emotional response in elite athletes. Journal of Martial Arts Anthropology. 2017; 17(2): 41-50.

23. Coallier M, Rouleau N, Bara F, Morin M. Visual-motor skills performance on the Beery-VMI: a study of Canadian kindergarten children. The Open Journal of Occupational Therapy. 2014; 2(2). https://doi.org/10.15453/2168-6408.1074

24. Matsumoto T, Ushiroyama T, Kimura T, Hayashi T, Moritani T. Altered autonomic nervous system activity as a potential etiological factor of premenstrual syndrome and premenstrual dysphoric disorder. BioPsychoSocial Medicine. 2007; 1(24): 1-24. https://doi.org/10.1186/1751-0759-1-24

25. Chaplin TM, Aldao A. Gender differences in emotion expression in children: a meta-analytic review. Psychological Bulletin. 2013; 139(4): 735-765. https://doi.org/10.1037/a0030737

26. Goodbody SJ, Wolpert DM. The effect of vasomotor displacements on arm movement paths. Exp Brain Res. 1999; 127(3): 213-223. https://doi.org/10.1007/s002210050791

27. Dmitrieva NV. [Electrophysiological mechanisms of development of adaptation processes]. Human Physiology. 2004; 30(3): 281-289 (in Russian). https://doi.org/10.1023/B:HUMP.0000029173.54032.fe

28. Makarenko MV, Ivaniura IO, Sheiko VI. [Investigation of psychophysiological functions of pupils of secondary school age with prolonged physical activity]. Physiological journal. 2002; 48(5): 56-61 (in Ukrainian).

29. Padilla-Medina JA, Prado-Olivarez J, Amador-Licona N, Cardona Torres LM, Galicia-Resendiz D, Diaz-Carmona J. Study on simple reaction and choice times in patients with type I diabetes. Comput. Biol. Med. 2013; 43(4): 368-376. https://doi.org/10.1016/j.compbiomed.2013.01.010

30. Vadziuk SN, Ratynska OM. [Sensorimotor reactions in students of high school age during different types of the weather]. Human Physiology. 2004; 50(1): 81-84 (in Ukrainian).

31. Bouma EMC, Riese H, Ormel J, Verhulst FC, Oldehinkel AJ. Adolescents' cortisol responses to awakening and social stress; Effects of gender, menstrual phase and oral contraceptives. The TRAILS study. Psychoneuroendocrinology. 2009; 34(6): 884-893. https://doi.org/10.1016/j.psyneuen.2009.01.003

32. Nikolaeva EN, Kolosova ON. [Physiological estimation of the state of the central nervous system of students in the period of educational activity]. Science and education. 2017; 3: 96-100 (in Russian).

33. Topchii MS. [Functional mechanisms of adaptation of youths of different ages to training loads (extended abstract of candidate's thesis)]. Cherkasy: Cherkasy National University named after Bohdan Khmelnytsky; 2018 (in Ukrainian).

34. Bosenko AI, Shumeiko KP. [Inventors: Department of Biology and Health of the South Ukrainian National Pedagogical University named after K. D. Ushinsky, assignee. A device for diagnosing the functional state of the human brain "Lightning"]. The patent of Ukraine No 20869. 2007 Feb 15 (in Ukrainian).

35. Vodlozerov VM, Tarasov SG. [Human visual-motor activity under tracking conditions]. Kharkov: Publishing House of the Humanitarian Center; 2002 (in Russian).

36. Shutova SV, Murav'eva IV. [Sensomotor reactions as a characteristic of the functional state of the central nervous system]. Bulletin TSU. 2013; 18(5): 2831-2840 (in Russian). 
37. Davidenko DN. [Method of assessing body's functional reserve mobilization in case of its response to controlled activity]. Scientific and theoretical journal "Scholarly notes of Lesgaft University". 2011; 12(70): 52-57 (in Russian).

38. Korenberg VB. [Sports metrology]. Moscow: Physical culture; 2008 (in Russian).

39. Rieger M, Knoblich G, Prinz W. Compensation for and adaptation to changes in the environment. Exp Brain Res. 2005; 163(4): 487-502. https://doi.org/10.1007/s00221-004-2203-8

40. Weems CF, Zakem AH, Costa NM, Cannon MF, Watts SE. Physiological response and childhood anxiety: association with symptoms of anxiety disorders and cognitive bias. Journal of Clinical Child and Adolescent Psychology. 2005; 34(4): 712-723. https://doi.org/10.1207/s15374424jccp3404_13

41. Baevskij RM, Berseneva AP, Luchickaja ES, Slepchenkova IN, Chernikova AG. [Assessment of the level of health in the study of practically healthy people: methodical guidance]. Moscow: Firm "Word"; 2009 (in Russian). 